\title{
PENGEMBANGAN LUMBUNG PAKAN PADA KELOMPOK TANI- TERNAK KERBAU SUMBAWA UNTUK PENINGKATAN PRODUKSI DAN PENDAPATAN PETERNAK DI DESA GAPIT, KECAMATAN EMPANG, KABUPATEN SUMBAWA
}

\author{
Suhubdy*1, Soekardono ${ }^{2}$, Anwar Fachry ${ }^{2}$, Sofyan D. Hasan ${ }^{1}$ \\ ${ }^{1)}$ Laboratorium Ilmu Nutrisi Ternak Ruminansia/Herbivora Fakultas Peternakan \\ Universitas Mataram, Indonesia \\ ${ }^{2)}$ Laboratorium Sosial Ekonomi Peternakan, Fakultas Peternakan \\ Universitas Mataram, Indonesia
}

\author{
Kata Kunci: \\ industri \\ peternakan, \\ kelompok tani- \\ ternak, kerbau \\ sumbawa, \\ lumbung pakan
}

\begin{abstract}
Abstrak: Desa Gapit adalah salah satu desa di Kecmatan Empang Kabupaten Sumbawa yang telah memiliki kelompok tani-ternak kerbau, yaitu kelompok "ABADI JAYA". Namun, kelompok tersebut belum berfungsi optimal sebagai wahana pengembangan usaha ternak kerbau. Para peternak masih memelihara ternak secara tradisional sehingga produksi dan produktivitas ternak masih rendah. Melalui pengabdian kepada masyarakat ini diharapkan kelompok tani-ternak tersebut dapat lebih maju dan mandiri. Tujuan pengabdian kepada masyarakat ini adalah, (1) untuk meningkatkan kemampuan manajemen sistem produksi ternak kerbau berbasis kelompok, dan (2) untuk memperbaiki sistem manajemen kelompok dan manajemen usaha. Pengabdian ini dilakukan pada kelompok taniternak "ABADI JAYA" di desa Gapit, Kecamatan Empang, Kabupaten Sumbawa. Kegiatan dalam pengabdian ini meliputi penyuluhan dan pelatihan kepada pengurus dan anggota kelompok tani-ternak sebanyak 20 orang yang dilaksanakan dalam dua kali pertemuan dalam dua bulan. Pertemuan pertama, memberikan motivasi dan penjelasan tentang sistem produksi ternak kerbau yang baik dengan penerapan panca usaha ternak kepada seluruh peternak anggota kelompok agar para peternak menyadari bahwa usaha ternak kerbau dapat menjadi sumber pendapatan utama bagi peternak. Pertemuan kedua, memberikan penyuluhan tentang manajemen usaha dan manajemen kelompok, meliputi bagaimana merencanakan usaha, kalkulasi biaya dan pendapatan, dan pemasaran ternak. Hasil pengabdian ini menunjukkan bahwa para peternak kerbau sangat termotivasi untuk mengembangkan usaha ternak kerbaunya dengan memajukan kelompok teni-ternaknya. Mereka mulai menyadari pengelolaan dengan menggunakan teknologi, terutama teknologi pakan sangat penting. Mereka menyatakan sanggup mengadakan lumbung pakan untuk mengatasi krisis pakan musim kemarau. Mereka juga menyatakan kesanggupannya untuk memajukan kelompok menjadi kelompok yang berorientasi bisnis.
\end{abstract}

Korespondensi: suhubdy@unram.ac.id; suhubdy1960@gmail.com

\section{PENDAHULUAN}

Kabupaten Sumbawa merupakan salah satu kabupaten di Provinsi Nusa Tenggara Barat (NTB) yang paling potensial untuk pengembangan ternak kerbau. Ternak kerbau yang hidup di seluruh wilayah NTB dikenal dengan nama kerbau sumbawa (Bubalus bubalis). Populasi kerbau sumbawa di Kabupaten Sumbawa tercatat sekitar 43.000 ekor pada tahun 2016, terbanyak dibanding dengan kabupaten-kabupaten lain di wilayah Provinsi Nusa 
Tenggara Barat. Namun perkembangan populasinya dari tahun ke tahun cenderung berkurang (Tabel 1).

Tabel 1. Perkembangan populasi ternak kerbau sumbawa di Kabupaten Sumbawa

\begin{tabular}{|c|c|c|}
\hline \multirow{2}{*}{ Tahun } & \multicolumn{2}{|c|}{ Kerbau sumbawa } \\
\cline { 2 - 3 } & Populasi (ekor) & Laju Pertumbuhan (\%) \\
\hline 2010 & 54,535 & NA \\
\hline 2011 & 55,706 & 2.15 \\
\hline 2012 & 54,022 & -3.02 \\
\hline 2013 & 50,857 & -5.86 \\
\hline 2014 & 49,752 & -2.17 \\
\hline 2015 & 45,595 & -8.36 \\
\hline 2016 & 43,340 & -4.95 \\
\hline
\end{tabular}

Sumber: Dinas Peternakan Kabupaten Sumbawa (2016).

Keterangan: NA $=$ not available

Kerbau sumbawa telah diakui sebagai salah satu rumpun kerbau di Indonesia berdasarkan Keputusan Menteri Pertanian Nomor 2910/Kpts/OT/2011. Kerbau sumbawa memiliki cirriciri diantaranya, berat badan kerbau dewasa berkisar antara $350 \mathrm{~s} / \mathrm{d} 400 \mathrm{~kg}$, usia beranak pertama sekitar 4 tahun, jarak beranak sekitar 17 bulan, induk diafkir sekitar 8 tahun (Suhubdy, 2013).

Kecamatan Empang merupakan wilayah yang paling banyak populasi kerbaunya, tercatat sebanyak 9,337 ekor, disusul oleh Kecamatan Moyo Hilir 5.678 ekor, Kecamatan Moyo Hulu 4.771 ekor, Kecamatan Lape 4.408, dan Kecamatan Tarano 3.253 ekor. Kecamatan-kecamatan lainnya hanya memiliki populasi di bawah 2.000 ekor. Di Desa Gapit Kecamatan Empang terdapat kelompok tani-ternak kerbau, yaitu kelompok tani-ternak "ABADI JAYA" dengan jumlah anggota 10 orang yang dibentuk pada tahun 2014. Jumlah ternak kerbau sumbawa dalam kelompok tersebut sekitar 200 ekor. Walaupun telah bergabung dalam kelompok tetapi pemeliharaan ternak sehari-hari masih secara individual dengan manajemen yang masih tradisional. Ternak kerbau sumbawa dilepas pada padang penggembalaan (Lar; Bahasa sumbawa). Permasalahan yang mulai dirasakan oleh para peternak adalah semakin berkurangnya areal padang penggembalaan akibat pergeseran pola penggunaan lahan yang menjadikan lar sebagai lahan pertanian. Kondisi demikian menyebabkan ketersediaan pakan menjadi berkurang.

Oleh karena itu, perlu adanya perubahan orientasi usaha ternak kerbau sumbawa yang semula ternaknya dipelihara secara ekstensif, di masa akan datang harus dilakukan secara intensif atau minimal secara semi-intensif. Pola pemeliharaan intensif atau semi intensif memerlukan penyediaan pakan dalam jumlah sesuai kebutuhan dan secara kontinyu. Penyediaan pakan ini memerlukan teknologi pengelolaan pakan, diantaranya yang penting adalah "manajemen logistik pakan". Manajemen logistik pakan meliputi bagaimana cara pengumpulan pakan, penyimpanan pakan, dan mendistribusikan atau pemberian pakan. Manajemen logistik pakan akan efisien dan efektif jika dilaksanakan dalam kelompok taniternak. Penerapan manajemen logistik pakan tersebut akan berlangsung dengan baik apabila pengurus kelompok telah memiliki pengetahuan, ketrampilan yang memadai tentang 
teknologi pakan dan memiliki etos kerja tinggi. Disamping itu, para peternak juga harus memilki kesadaran tentang pentingnya aplikasi teknologi. Dalam upaya menuju ke arah usaha ternak kerbau sumbawa yang intensif, perlu dilaksanakan penyuluhan dan pelatihan tentang teknologi peternakan kerbau, terutama teknologi pakan.

Oleh karena itu, terkait dengan pengabdian ini, permasalahan yang ingin di selesaikan dikonsentrasikan pada dua hal, yaitu pengetahuan dan ketrampilana teknik produksi dari para peternak terutama teknik pengelolaan pakan dan manajemen kelompok tani-ternak bagi pengurus kelompok. Permasalahan yang terkait dengan pakan, diupayakan agar para peternak mampu dan mau membangun lumbung pakan untuk mengatasi krisis pakan di musim kemarau. Permasalahan terkait dengan manajemen usaha dan kelompok, diarahkan agar kelompok tani-ternak mengoptimalkan fungsi kelompok sebagai unit bisnis.

\section{METODE KEGIATAN}

Metode yang digunakan dalam kegiatan PPM ini adalah penyuluhan/pelatihan kelompok. Metode ini pada dasarnya bertujuan untuk meningkatkan pengetahuan, ketrampilan, dan sikap/tindakan para peternak sehingga mereka mau dan mampu menerapkan teknologi dalam usaha ternaknya sehingga pendapatan usahanya meningkat. Penyuluhan/pelatihan dilaksanakan dalam kelompok tani-ternak. Secara rinci, tahapan dan metode penyuluhan/pelatihan dimaksud adalah sebagai berikut (Tabel 2).

Tabel 2. Metode Pengabdian kepada masyarakat yang telah dilaksanakan

\begin{tabular}{|c|l|l|}
\hline No & \multicolumn{1}{|c|}{ Kegiatan } & \multicolumn{1}{|c|}{ Metode } \\
\hline 1 & $\begin{array}{l}\text { Memberi motivasi dan penyuluhan tentang } \\
\text { manajemen produksi ternak kerbau }\end{array}$ & $\begin{array}{l}\text { Ceramah dan diskusi satu } \\
\text { sesi selama 2 jam. }\end{array}$ \\
\hline 2 & $\begin{array}{l}\text { Pelatihan pembuatan pakan berbasis jerami dan } \\
\text { hasil sisa tanaman pangan dan penyimpanann } \\
\text { serta cara pemberian pakan dalam rangka } \\
\text { membangun lumbung pakan }\end{array}$ & $\begin{array}{l}\text { Ceramah, diskusi, dan } \\
\text { praktek dua sesi masing- } \\
\text { masing 2 jam }\end{array}$ \\
\hline 3 & $\begin{array}{l}\text { Penyuluhan manajemen kelompok dan } \\
\text { manajemen usaha kepada pengurus dan anggota } \\
\text { kelompok }\end{array}$ & $\begin{array}{l}\text { Ceramah dan diskusi dua } \\
\text { sesi, masing-masing selama } \\
\text { 2 jam }\end{array}$ \\
\hline
\end{tabular}

Khusus pelatihan pembuatan pakan akan diberikan materi pembuatan hay jerami jagung /padi/kedelai/kacang hijau. Jerami jagung merupakan hasil ikutan tanaman jagung dengan tingkat produksi mencapai 4-5 ton/ha (Soekardono dan Fachry, 2017). Kandungan nutrisi jerami jagung diantaranya adalah protein $5,56 \%$, serat kasar 33,58\%, lemak kasar 1,25, a bu 7,28 dan BETN 52,32\%. Kualitas jerami jagung sebagai pakan ternak dapat ditingkatkan dengan teknologi silase yaitu proses fermentasi yang dibantu jasad renik dalam kondisi anaerob (tanpa oksigen). Teknologi silase dapat mengubah jerami jagung dari sumber pakan berkualitas rendah menjadi pakan berkualitas tinggi serta sumber energi bagi ternak. Bangunan dan peralatan pembuatan silase jagung disebut Silo. Bentuk silo berupa bangunan berbentuk silinder atau bunker yang dapat ditutup rapat. Cara lain pembuatan silase yaitu dengan membuat lubang seperti sumur yang diberi alas plastik. Selain itu dapat juga digunakan drum yang terbuat dari plastik. Peralatan yang digunakan dalam pembuatan silase antara lain alat pencacah hijauan, plastik atau bahan lain yang kedap udara. 


\section{HASIL DAN PEMBAHASAN}

Kegiatan pengabdian kepada masyarakat ini dilakukan pada kelompok tani-ternak "ABADI JAYA" di desa Gapit, Kecamatan Empang, Kabupaten Sumbawa. Kegiatan utama pengabdian kepada masyarakat ini adalah penyuluhan dan pelatihan bagi para pengurus dan peternak anggota kelompok. Peserta yang terlibat dalam pelatihan sebanyak 25 orang, termasuk pengurus kelompok. Penyuluhan dan pelatihan dilaksanakan selama 2 (tiga) hari, setiap hari terdiri dari tiga sesi. Pada hari pertama, diberikan motivasi kepada para peternak melalui ceramah dan diskusi dengan tujuan memberi semangat untuk meningkatkan usaha ternak kerbaunya kearah usaha komersial (bisnis), dilanjutkan dengan ceramah dan diskusi tentang manajemen produksi ternak kerbau. Pada hari kedua, diberikan penyuluhan dan pelatihan tentang logistik pakan dan manajemen kelompok dan usaha ternak kerbau.

\section{Pencapaian Tujuan}

Tujuan utama pengabdian kepada masyarakat ini adalah meningkatkan pengetahuan dan ketrampilan para peternak mengenai teknologi produksi ternak (feeding, breeding, dan management) dan mengenai manajemen usaha dalam kelompok. Pelaksanaan pengabdian kepada masyarakat ini berlangsung dengan baik. Selama penyuluhan dan pelatihan, para peserta (pengurus dan anggota kelompok) sangat aktif dalam diskusi, mulai dari penyampaian masalah-masalah sampai kepada rencana penyelesaian masalah. Masalah-masalah yang dialami para peternak adalah (1) semakin berkurangnya areal padang penggembalaan karena semakin meningkatnya konversi lahan untuk aktivitas pertanian (persawahan) sehingga penyediaan pakan semakin berkurang, terutama pada musim kemarau, (2) manajemen produksi ternak masih tradisional, belum menerapkan teknologi produksi ternak, (3) manajemen kelompok dan manajemen usaha belum dilakukan dengan optimal.

Selama empat tahun terakhir, sejak berdirinya kelompok tahun 2014, perkembangan kelompok tani-ternak "ABADI JAYA" tidak signifikan atau dapat dikatakan stagnan. Jumlah ternak kerbau relatif tidak berubah, tetap hanya sekitar 200 ekor. Kondisi ternak relatif tidak optimal, banyak induk yang umur afkir tetap dipelihara (Gambar 1).

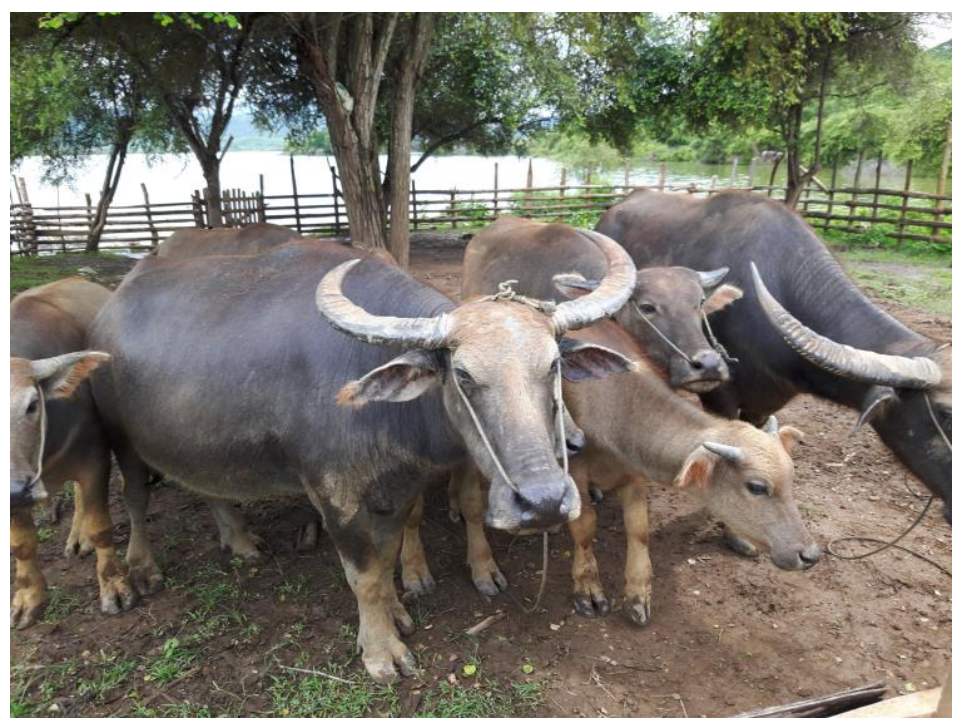

Gambar 1. Visualisasi induk kerbau sumbawa milik anggota kelompok tani-ternak "ABADI JAYA" (CSuhubdy, 2019) 


\section{Pencapaian Sasaran}

Sasaran pengabdian kepada masyarakat ini adalah petani-peternak yang tergabung dalam kelompok tani-ternak "ABADI JAYA". Jumlah petani-peternak yang berpartisipasi dalam pelatihan dalam rangka pengabdian kepada masyarakat ini sebanyak 19 orang. Jumlah anggota kelompok sebanyak 22 orang. Dengan demikian jumlah peserta pelatihan sebanyak 86\% dari seluruh anggota kelompok. Dilihat dari jumlah dan keaktifan peserta selama pelatihan, sasaran pengabdian kepada masyarakat ini dapat dikatakan berhasil.

Output pengabdian kepada masyarakat ini adalah para peternak memiliki ketrampilan teknis dan ekonomis dalam berusaha ternak kerbau. Secara teknis, para peternak sebenarnya telah trampil dalam melaksanakan panca usaha ternak kerbau, yaitu pemilihan bibit, pemberian pakan, pemeliharaan sehari-hari, penanganan reproduksi ternak (perkawinan ternak), dan penanganan kesehatan ternak. Namun demikian, mereka belum menerapkannya dengan baik. Sebagai contoh, banyak peternak yang masih mempertahankan induk kerbau yang berumur di atas 10 tahun dengan alasan kerbau tersebut bersejarah baginya (Gambar 1). Setelah mengikuti penyuluhan, para peternak telah memiliki pengetahuan manajemen bisnis seperti mengalokasikan sumber daya secara efisien, menentukan jumlah pemeliharaan kerbau yang optimal, menentukan kapan ternak harus dijual, menentukan harga jual, dan sebagainya. Khusus pengelolaan pakan, selama ini para peternak belum menerapkan teknologi. Seharihari ternak digembalakan di padang penggembalaan dan sore harinya dikandangkan di kandang kolektif (Gambar 2).

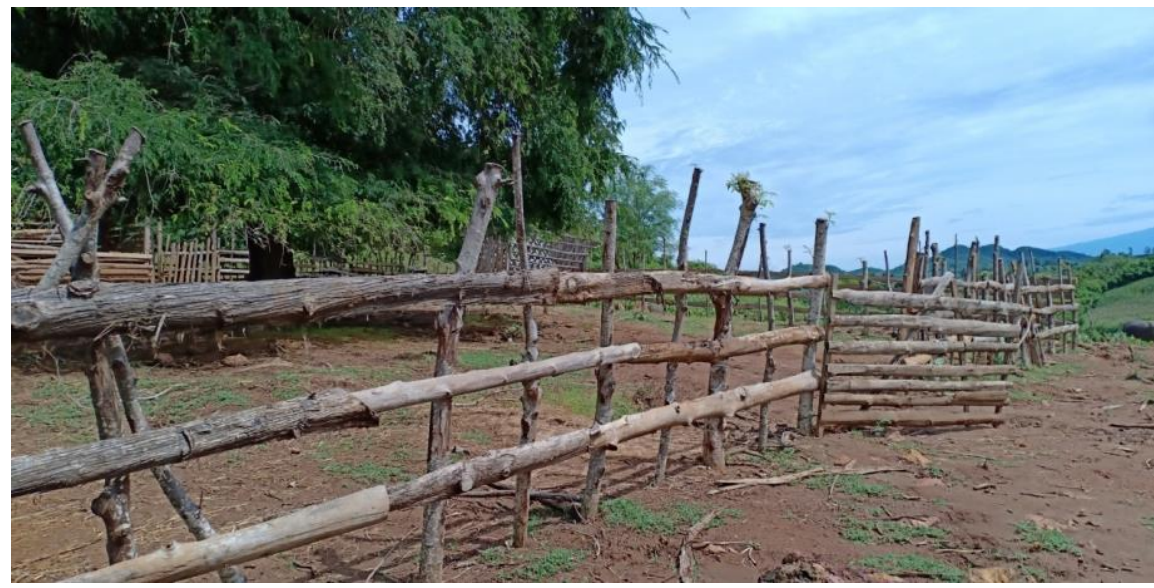

Gambar 2. Visualisasi kondisi kandang kelompok milik tani-ternak kerbau sumbawa "ABADI JAYA" (CSuhubdy, 2019)

\section{Pencapaian Manfaat}

Manfaat pengabdian kepada masyarakat bagi para peternak adalah menambah pengetahuan dan ketrampilan berternak dan menambah ketrampilan manajerial dalam berusaha ternak kerbau. Setelah mengikuti penyuluhan/pelatihan para peternak merasa mendapat semangat baru untuk mengembangkan usaha ternak kerbaunya kearah usaha yang lebih menguntungkan. Para peternak mulai menyadari bahwa dengan penerapan teknologi pakan (Gambar 3) akan dapat meningkatkan produksi, produktivitas, dan jumlah pemeliharaan ternak. Para peternak belum memanfaatkan jerami tanaman pertanian secara 
optimal. Jerami padi dan jerami jagung kering jarang dimanfaatkan oleh petani-peternak. Dengan jumlah pemeliharaan terbatas (4-5 ekor), para peternak masih dapat menyediakan pakan berupa hijauan segar. Selama ini para peternak berpikir (mindset) bahwa jerami kering tidak baik untuk pakan ternak. Setelah mengikuti pelatihan, nampaknya para peternak mulai menyadari bahwa dengan teknologi pakan, jerami kering dapat dijadikan stok pakan.

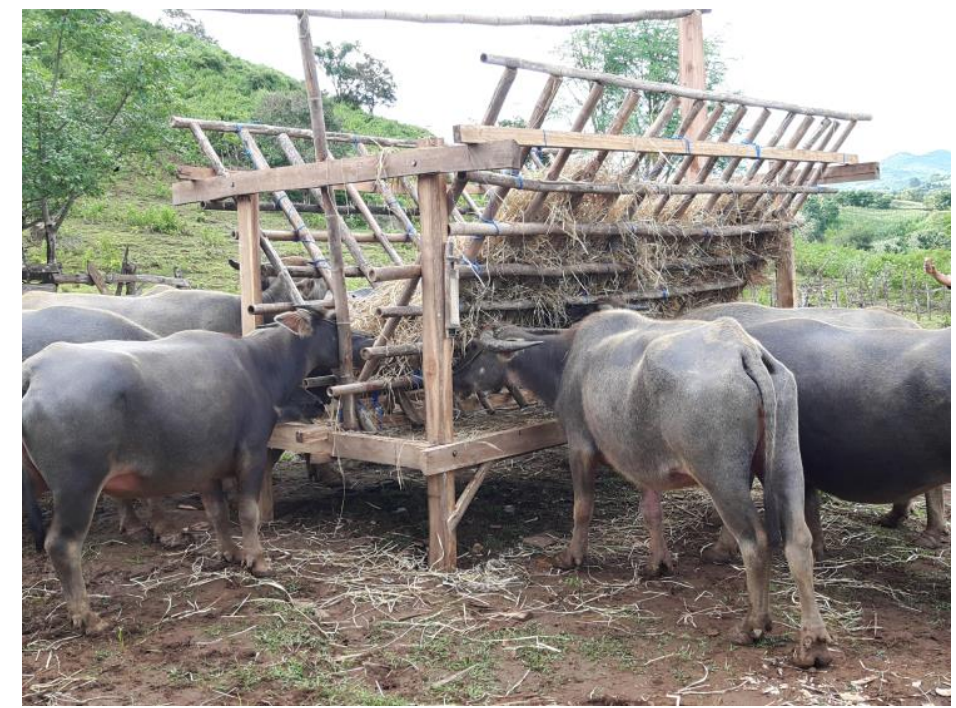

Gambar 3. Visualisasi Pakansia yang dibangun untuk kelompok tani-ternak kerbau sumbawa, "ABADI JAYA" (CSuhubdy, 2019).

Manfaat untuk institusi akademik (misalnya: Fakultas Peternakan Universitas Mataram), program pengabdian kepada masyarakat ini dapat menjadi jembatan penghubung antara fakultas sebagai sumber teknologi dengan para peternak sebagai pelaku utama usaha ternak yang membutuhkan teknologi. Melalui pengabdian kepada masyarakat, fakultas dapat mendiseminasikan hasil-hasil penelitian para dosen dan mahasiswa kepada para peternak sekaligus dapat memperoleh umpan balik mengenai masalah-masalah yang dialami para peternak. Disamping itu, lokasi pengabdian kepada masyarakat dapat dikembangkan menjadi tempat praktek kerja lapangan (PKL) mahasiswa.

Manfaat untuk pemerintah, kelompok tani-ternak yang telah menerapkan teknologi peternakan dan telah menerapkan manajemen usaha berorientasi bisnis, dapat dijadikan percontohan dalam rangka pengembangan usaha ternak kerbau yang lebih produktif dan menguntungkan. Usaha ternak kerbau yang produktif akan mendukung tercapainya program NTB-BSS dan sekaligus mendukung program swasembada daging sapi dan kerbau nasional (PSDS/K).

\section{Faktor Penghambat dan Pendorong}

Beberapa faktor penghambat dalam pengembangan usaha ternak kerbau, khususnya pada kelompok tani-ternak "ABADI JAYA" adalah:

1) Para peternak secara turun temurun memelihara ternak kerbau secara ekstensiftradisional. Sehari-hari ternak kerbau digembalakan di padang penggembalaan. Penyediaan tambahan pakan hanya diberikan pada musim kemarau. Pada musim hujan, 
pakan hijauan cukup melimpah sehingga ternak-ternak kerbau cukup dengan merumput pada padang penggembalaan. Sebaliknya, pada musim kemarau ketersediaan pakan hijauan pada padang penggembalaan sangat terbatas sehingga memerlukan tambahan pakan di kandang. Kondisi demikian menyebabkan jumlah kerbau yang dapat dipelihara oleh rumah tangga tani-ternak menjadi terbatas.

2) Para petani-peternak berpikiran bahwa usaha ternak kerbau hanya sebagai usaha sambilan dan tabungan sedangkan usaha pokoknya adalah usahatani tanaman pangan. Pemikiran demikian mengakibatkan para petani-peternak mengusahakan ternak kerbau sumbawa secara tradisional, tidak mengembangkannya dengan menggunakan prinsipprinsip bisnis peternakan.

3) Kelompok tani-ternak belum berfungsi optimal sebagai kelompok yang berorientasi bisnis. Kelompok masih berfungsi sebagai kandang kolektif, yang lebih berfungsi sebagai tempat penampungan sementara terutama jika ada kegiatan registrasi, pemberian tanda (telinga dan cap bakar) dan pemeriksaan kesehatan. Kelompok belum melakukan manajemen untuk efisiensi usaha, misalnya dalam penyediaan bibit ternak, penyediaan pakan, pembuatan pupuk organik, pemasaran ternak, pengembangan skala usaha, dan sebagainya. Selama ini para peternak melakukan kegiatan dalam usaha ternak kerbaunya secara sendiri-sendiri.

4) Pengurus kelompok kurang aktif dalam mengelola kegiatan kelompok, masih sangat tergantung pada pembinaan petugas Dinas Peternakan. Sementara ini petugas Dinas Peternakan relatif kurang aktif dan tidak berkelanjutan dalam membina kelompok taniternak.

Beberapa faktor pendorong dan peluang, adalah:

1). Lahan di wilayah Desa Gapit tergolong luas dan subur (terdapat Bendungan Gapit). Sebagian besar lahan pertanian ditanami jagung sehingga jerami jagung cukup tersedia sebagai sumber pakan. Di lahan tegal/kebun cukup subur dan ditumbuhi oleh tetumbuhan seperti rumput lapangan (field grass) dan/atau palawija.

2). Para peternak di wilayah ini telah berpengalaman memelihara kerbau sumbawa secara turun temurun dan memiliki keinginan dan kemauan yang kuat untuk mengembangkan usaha ternak kerbaunya dalam rangka menambah pendapatan rumah tangganya.

3). Permintaan ternak kerbau sumbawa baik sebagai kerbau pedaging maupun kerbau perah dan bibit sangat besar, sehingga tidak ada permasalahan dalam pemasaran ternak.

4). Institusi pendukung cukup tersedia untuk melayani para peternak dalam pengembangan usaha ternak kerbau sumbawa, seperti Puskeswan, Lembaga Penyuluhan, dan Perbankkan serta UPT Perbibitan kerbau sumbawa.

\section{KESIMPULAN DAN SARAN}

Kabupaten Sumbawa memiliki keunggulan komparatif untuk mengembangan ternak kerbau dibandingkan dengan kabupaten-kabupaten lain di NTB. Kabupaten Sumbawa telah dinobatkan sebagai "Kabupaten Peternakan" (Deklarasi Samawa, 2006) untuk mengembangan ternak kerbau di Indonesia dengan ditetapkannya kerbau sumbawa sebagai salah satu sumberdaya genetik Indonesia. Untuk menunjang kegiatan tersebut, Pemerintah Kabupaten Sumbawa telah membangun Unit Pelaksana Teknis (UPT) Perbibitan dan 
Pusat Penelitian Kerbau sumbawa Bersinergi, yang berlokasi di wilayah Kecamatan Maronge. Namun demikian, selama ini populasi ternak kerbau sumbawa cenderung tidak menunjukkan adanya perkembangan yang menggembirakan. Oleh karena itu, hasil kegiatan penyuluhan dan pelatihan dalam rangka pengabdian kepada masyarakat ini perlu ditindaklanjuti dan pedomani untuk pengembangan selanjutnya

\section{DAFTAR PUSTAKA}

Borghese, A. 2005. Buffalo Production and Research. REU Technical Series 67, FAO Regional Office for Europe, FAO, Rome, Italy.

Dinas Peternakan Kabupaten Sumbawa. 2016. Laporan Tahunan Dinas Peternakan dan Kesehatan Hewan. Kabupaten Sumbawa, Sumbawa Besar.

Dirjen PKH. 2006. Prosiding Lokakarya Nasional Usaha Ternak Kerbau. Sumbawa Besar, 45 Agustus 2006. Dinas Peternakn Kabupaten Sumbawa dan Dirjen PKH, Deptan RI, Jakarta.

FAO. 1977. The Water Buffalo. FAO Animal Production and Health No. 4. FAO, The United Nations, Rome - Italy.

Heriyanto, E., Amrizal Aanas, dan Ediset. 2018. Penyuluhan Peningkatan Mutu Pakan Dalam Upaya Perbaikan Usaha Peternakan di Kelompok Tani Kerbau Antrada, Kabupaten Dharmasraya, Sumatera Barat. Conference on Innovation and Application of Sience and Technology (CIASTECH 2018) Universitas Widyagama Malang, 12 September 2018. ISBN cetak: 2622-1276. ISBN Online: 2622-1284.

Soekardono dan A. Fachry. 2017. Corn and Cattle Integration to Sport NTB's One Million Cattle Programe in Lombok Island. Proceedings The $7^{\text {th }}$ International Seminar On Tropiccal Animal Production, September 12-14, 2017, Yogyakarta, Indonesia. ISBN: 978-979-1115-29-9.

Paul, S.S. and Lal, D. 2010. Nutrient Requirements of Buffaloes. Satish Serial Publishing House, Azadpur, Dehli, India.

Suhubdy, Soekardono, dan A Fachry. 2017. Analisis potensi ternak kerbau dan sapi berbasis desa dan skenario pengembangannya di Kabupaten Sumbawa. Laporan Penelitian. Kerjasama Dinas Peternakan dan Kesehatan Hewan Kabupaten Sumbawa dengan Recent Trend and Gaps-Fakultas Peternakan Universitas Mataram. Mataram NTB,

Suhubdy. 2013. Produksi Termak Ruminansia (Kerbau dan Sapi). Pustaka Reka Cipta, Bandung.

Suhubdy. 2007a. Strategi penyediaan pakan untuk pengembangan usaha ternak kerbau. Wartazoa Vol. 17 No. 1: 1-11.

Suhubdy. 2007b. Nutritional reproduction of Indonesian Buffalo: An experience from Sumbawa Buffalo. Buffalo Newsletter, Rome, Italy 